\title{
EPISTEMOLOGI DAN RUMPUN KEILMUAN KOMUNIKASI PENYIARAN ISLAM
}

\author{
Mohammad Zamroni \\ Universitas Islam Negeri (UIN) Sunan Kalijaga Yogyakarta \\ Email: mohammad.zamroni@uin-suka.ac.id
}

\begin{abstract}
As a field of scientific discipline, the existence of Islamic communication and broadcasting still seems to be an unanswerable question. The issue is often addressed on how the epistemology and the clumps of communication and broadcasting science is. To meet this problem, in-depth studies need to be done by tracing the philosophy of science as a basic science including ontology, epistemology, and axiology. This study is needed to dismiss such dichotomy between secular sciences and the religious sciences (Islam). An integrative-interconnected science paradigm becomes a reference of the approach to integrate between science and Islam. Thus, the epistemology of communication science is a scientific discipline that studies broadcasting and journalism like others. While the Islamic Broadcasting Studies is a field of Da'wa study that becomes a core value of the Islamic perspective.

Sebagai bidang disiplin ilmu, adanya komunikasi Islam dan penyiaran nampaknya masih menjadi pertanyaan yang tidak terjawab. Masalah ini sering ditujukan pada bagaimana epistemologi dan rumpun komunikasi dan ilmu penyiaran. Untuk memenuhi masalah ini, studi perlu dilakukan secara mendalam dengan menelusuri filsafat ilmu sebagai ilmu dasar termasuk ontologi, epistemologi, dan aksiologi. Penelitian ini diperlukan untuk mengabaikan dikotomi seperti antara ilmu-ilmu sekuler dan ilmu-ilmu agama (Islam). Paradigma ilmu integratif-saling berhubungan menjadi acuan dari pendekatan untuk mengintegrasikan antara ilmu pengetahuan dan Islam. Dengan demikian, epistemologi ilmu komunikasi adalah suatu disiplin ilmu yang mempelajari penyiaran dan jurnalisme seperti orang lain. Sementara Studi Broadcasting Islam adalah bidang studi Dakwah yang menjadi nilai inti dari perspektif Islam.
\end{abstract}

Keywords: Epistemology, clumps scientific, communications, and broadcasting islam. 


\section{A. Pendahuluan}

UIN Sunan Kalijaga Yogyakarta dalam perkembangan sejarah lahirnya, telah menunjukkan perubahan yang cukup radikal terlebih pasca konversi dari IAIN menjadi UIN pada tahun 2004. Salah satu perubahan besar ditandai dengan lahirnya Fakultas dan Jurusan/Program Studi yang disiplin keilmuannya bercorak umum. Sebut saja misalnya, Fakultas Sains dan Teknologi (F. Saintek) dengan munculnya program studi Matematika, Fisika, Kimia, Biologi, Teknik Informatika, Teknik Industri, Pendidikan Matematika, Pendidikan Fisika, Pendidikan Kimia, dan Pendidikan Biologi. Demikian juga, telah dilahirkan Fakultas Ilmu Sosial dan Humaniora (Fishum) yang di dalamnya terdapat program studi Sosiologi, Psikologi, dan Ilmu Komunikasi.

Lahirnya Fakultas dan Program Studi baru di atas, mengalami perkembangan cukup pesat sekaligus melahirkan pertentangan dan permasalahan yang belum terselesaikan. Salah satunya permasalahan yang menonjol adalah terindikasi adanya tumpang tindih antar program studi dengan Fakultas lainnya yang lebih dulu lahir. Hal ini lebih disebabkan karena belum kokohnya rumpun keilmuan masing-masing. Satu diantaranya adalah Jurusan Komunikasi dan Penyiaran Islam Fakultas Dakwah dan Komunikasi yang tampak berbenturan dengan program studi Ilmu Komunikasi Fakultas Ilmu Sosial dan Humaniora. Benturan inipun berakibat luas dampaknya baik soal pilihan konsentrasi program studi, pembidangan keilmuan, tenaga pendidik, sarana prasarana, laboratorium pendidikan, dan sampai pada perebutan dalam penerimaan calon mahasiswa.

Berdasarkan fakta-fakta di atas, menjadi urgen kajian tentang Epistemologi dan Rumpun Keilmuan Jurusan Komunikasi dan Penyiaran Islam Fakultas Dakwah dan Komunikasi UIN Sunan Kalijaga untuk ditelaah lebih mendalam. Hal ini mengingat Jurusan Komunikasi dan Penyiaran Islam merupakan bagian integral dalam Fakultas Dakwah dan Komunikasi UIN Sunan Kalijaga Yogyakarta yang selama ini ikut andil dalam pengembangan keilmuan dan peradaban Islam. Sebagai salah satu penyelenggara pendidikan tinggi yang mengupayakan pembentukan sumber daya manusia yang berkualitas dan kompeten dengan mendidik, membina dan mengembangkan mahasiswanya untuk dipersiapkan sebagai sarjana dakwah dan komunikasi Islam yang mampu berkiprah di seluruh sendi kehidupan di masyarakat sesuai kompetensi dan keahliannya. Masalah ini bukan hanya menjadi persoalan pada sisi mahasiswa tetapi juga pada sisi Fakultas Dakwah dan Komunikasi UIN Sunan Kalijaga 
Yogyakarta secara keseluruhan. Jika Jurusan Komunikasi dan Penyiaran Islam tidak memiliki epistemologi dan rumpun keilmuan yang jelas, bagaimana bisa melanjutkan keberlangsungan hidup jurusan ini.

\section{B. Pembahasan}

\section{Keilmuan Integratif-Interkonektif: Paradigma Keterpaduan Islam dan Sains UIN Sunan Kalijaga}

Jargon integratif-interkonektif memang cukup populer di dengar terutama bagi kalangan civitas akademika UIN Sunan Kalijaga Yogyakarta. Jargon ini tidak hanya sekedar jargon pasca peralihan IAIN menjadi UIN tetapi lebih dari itu menjadi core values dan paradigma yang akan dikembangkan UIN Sunan Kalijaga yang mengisyaratkan tidak ada lagi dikotomi antara ilmu agama dan ilmu umum. Gagasan integratifinterkonektif ini muncul dari mantan rektor UIN Sunan Kalijaga Amin Abdullah yang kemudian mengaplikasikannya dalam pengembangan IAIN menjadi UIN. Teknologi yang semakin canggih sehingga tidak ada lagi sekat-sekat antar bangsa dan budaya, persoalan migrasi, revolusi IPTEK, genetika, pendidikan, hubungan antar agama, gender, HAM dan lain sebagainya. Perkembangan zaman mau tidak mau menuntut perubahan dalam segala bidang tanpa tekecuali pendidikan keislaman, karena tanda adanya respon yang cepat melihat perkembangan yang ada, maka kaum muslimin akan semakin jauh tertinggal dan hanya akan menjadi penonton, konsumen bahkan korban di tengah ketatnya persaingan global. Menghadapi tantangan era globlalilasi ini, umat Islam tidak hanya sekedar butuh untuk survive, tetapi bagaimana bisa menjadi garda depan perubahan. Hal ini kemudian dibutuhkan reorientasi pemikiran dalam pendidikan Islam dan rekonstruksi sistem kelembagaan.

Pemikiran M Amin Abdullah ${ }^{1}$ dari Normativitas-historisitas menuju Integratif-interkonektif paling tidak bermuara pada dua hal yang penting. Pertama, adalah persoalan pemahaman terhadap keislaman yang selama ini dipahami sebagai dogma yang baku, hal ini karena pada umumnya normativitas ajaran wahyu ditelaah lewat pendekatan doktrinal teologis. Pendekatan ini berangkat dari teks kitab suci yang pada akhirnya membuat corak pemahaman yang tekstualis dan skripturalis. Sedangkan di sisi lain untuk melihat historisitas keberagamaan manusia, pendekatan sosial

1 Abdullah, M. Amin, Islamic Studies di Perguruan Tinggi: Paradigma IntegratifInterkonektif, Cet II. (Yogyakarta: Pustaka Pelajar, 2010), hlm. 361-399 
keagamaan digunakan melalui pendekatan historis, sosiologis, antropologis dan lain sebagainya, yang bagi kelompok pertama dianggap reduksionis.

Pendekatan ini bagi Amin Abdullah merupakan hubungan yang seharusnya tidak dapat dipisahkan satu sama lain. Kedua jenis pendekatan ini-pendekatan yang bersifat teologis-normatif dan pendekatan yang bersifat histories-empiris ini sangat diperlukan dalam melihat keberagamaan masyarakat pluralistik. Kedua pendekatan ini akan saling mengoreksi, menegur dan memperbaiki kekurangan yang ada pada kedua pendekatan tersebut. Karena pada dasarnya pendekatan apapun yang digunakan dalam studi agama tidak akan mampu menyelesaikan persoalan kemanusiaan secara sempurna. Pendekatan teologis-normatif saja akan menghantarkan masyarakat pada keterkungkungan berfikir sehingga akan muncul truth claim sehingga melalaui pendekatan historiesempiris akan terlihat seberapa jauh aspek-aspek eksternal seperti aspek sosial, politik dan ekonomi yang ikut bercampur dalam praktek-praktek ajaran teologis.

Sedangkan yang kedua adalah paradigma keilmuan integratifinterkonektif. Paradigma ini juga dibangun sebagai respon atas persoalan masyarakat saat ini dimana era globalilasi banyak memunculkan kompleksitas persoalan kemanusiaan. Mempertemukan teori-teori dan metodologi ilmiah dengan membangun ilmu-ilmu keislaman adalah satu langkah yang valid untuk dilakukan, sehingga akan terjadi interaksi dialog yang kreatif di antara komponen-komponen dengan acuan dasar filsafat ilmu.

Sudah bukan masanya lagi, keilmuan itu berdiri sendiri secara terpisah-pisah (separated entities), apalagi angkuh tegak kokoh sebagai yang tunggal (single entity). Tingkat peradaban kemanusiaan saat ini yang ditandai dengan semakin melesatnya kemajuan dan kecanggihan teknologi informasi, tidak memberi alternasi lain bagi entitas keilmuan kecuali saling berangkulan dan tegur sapa, baik pada level filosofis, materi, strategi atau metodologinya. Itulah yang dimaksud dengan pola pendekatan integrasiinterkoneksi. Apabila tidak memungkinkan dilakukan proses integrasi, maka dengan menggunakan pendekatan interkoneksi bila menjadi pilihannya.

Amin Abdullah menunjukkan falsafah Islam tidak bisa hidup tanpa bergumul dengan falsafah barat dan falsafah barat sering kali juga tumpul, bahkan seringkali kehilangan "kompas" petunjuk arah kemana kapal akan 
berlabuh, ${ }^{2}$ jika tanpa berani mengambil masukan yang datang dari luar dirinya sendiri. dapat dikawinkan sedemikian rupa.

Hanya dengan kerangka kerja yang demikianlah, makna carrigibility (dapat dikoreksi) dan falsibility (dapat salah) dari ilmu-ilmu keislaman dapat dipahami dengan baik, sehingga adanya paradigma dan teori-teori yang kompetitif menjadi dimungkinkan. Lebih jauh lagi, konteks penemuan-penemuan baru (context of discovery) dalam ilmu-ilmu keislaman dan riset dapat berkembang dan mendapat prioritas, sementara konteks justifikasi (context of justification) dapat ditekan menjadi sekecil mungkin. Dalam jaringan kerja akademik semacam ini ilmu-ilmu keislaman dalam tradisi umat muslim tidak hanya akan "mereproduksi" paradigma lama yang secara umum telah diterima, akan tetapi juga mengkritisinya dan bahkan mungkin menggantinya dengan yang baru. Reformasi dan rekonstruksi yang sedemikian memang seringkali kurang berfungsi dalam rentang waktu jangka pendek, sering menimbulkan revolusi dan keresahan sosial, namun dalam jangka panjang akan berfungsi dengan baik. Anomalianomali dan inkonsistensi-inkonsistensi yang terkandung dalam setiap teori dan metodologi dalam ilmu-ilmu keislaman dengan begitu akan mudah dapat dideteksi, sehingga tradisi investigasi yang terus menerus dan tradisi riset yang berkelanjutan dengan menggunakan pendekatan interdisipliner dan multidisiplin dapat terpelihara dengan baik. ${ }^{3}$

\section{Epistemologi dan Rumpun Keilmuan Jurusan Komunikasi Penyiaran Islam}

Berdasarkan analisis objek formal Ilmu Dakwah dan relevansinya dengan pengembangan jurusan sudah dijelaskan oleh Salmadanis melalui seminar regional jurusan dakwah yang bertema "Menggagas Kembali Eksistensi Ilmu Dakwah". Menurutnya, untuk lebih menjelaskan ke mana arah dan tujuan jurusan di Fakultas Dakwah, maka perlu ditelusuri akar pemikiran yang berkaitan dengan aspek epistemologi dakwah dan dikaitkan dengan unsur-unsur dakwah yang mengitarinya.

Kegiatan dakwah mempunyai beberapa unsur, antara unsur satu dengan yang lainnya mempunyai interaksi dan inter relasi. Unsur pertama adalah doktrin Islam (A), unsur kedua adalah $d a^{\prime} i$ atau komunikator, baik sebagai individu maupun lembaga (B). Unsur ketiga adalah mad'u atau

2 Gerad Radnitzky, Contemporar School of Metascience (Swedia: Berlingska Broktryckercit, 1970), hlm. 161.

3 Ibid., hlm. 67. 
komunitas (C), dan unsur keempat adalah tujuan dakwah (D). Interaksi dan interrelasi antara keempat unsur dakwah tersebut melahirkan berbagai macam produk dakwah. Salah satu dari hasil interaksi dan interrelasi unsur-unsur antara B $\left(d^{\prime} a^{\prime}\right)$ dan $\mathrm{C}\left(\mathrm{mad}^{\prime} u\right)$ melahirkan pemikiran cara penyampaian dakwah secara lisan dan tulisan, yang dikenal dengan tabligh (menyampaikan) yang didalamnya mengandung dua dimensi kekuatan; Komunikasi dan Penyiaran Islam. Inilah zona Jurusan Komunikasi dan Penyiaran Islam (KPI), kegiatan yang berdimensi massa dan kegiatan terlembaga.

Dari penjelasan Salmadanis dapat disimpulkan bahwa arah dan tujuan dasar Jurusan Komunikasi dan Penyiaran Islam (KPI) adalah kegiatan yang berdimensi massa dan terlembaga. Artinya bagaimana Jurusan Komunikasi dan Penyiaran Islam (KPI) membentuk/menghasilkan output $d a^{\prime} i /$ komunikator yang professional baik lisan maupun tulisan. Bagaimana menyiarkan Islam (dakwah) dalam bentuk komunikasi kelompok maupun dalam bentuk komunikasi massa baik cetak maupun elektronik.

Untuk mengkaji suatu disiplin keilmuan maka ada baiknya perlu ditelaah juga unsur-unsur keilmuan yang meliputi ontologi, epistemologi, dan aksiologinya. Demikian halnya, pembahasan ini dalam kerangka untuk menelaah jurusan Komunikasi dan Penyiaran Islam masuk dalam rumpun keilmuan yang mana dan sekaligus menggambarkan konstruksi keilmuannya. Konsep keilmuan integrative-interkoneltif digunakan untuk memadukan antara paradigma sains dan Islam sehingga tidak ada dikotomi antara keilmuan dengan keislaman.

Satu di antara tiga aspek filsafat dalam membangun kerangka keilmuan suatu disiplin ilmu adalah membicarakan epistemologi suatu ilmu. Pembahasan mengenai epistemologi ilmu adalah pengkajian terhadap terjadinya pengetahuan, sumber pengetahuan, asal mula pengetahuan, teori kebenaran, metode-metode ilmiah dan aliran-aliran teori pengetahuan. Jika dirangkai lebih jauh, epistemologi ilmu sebenarnya muncul dari beberapa pertanyaan yang mendasar tentang pengetahuan. Plato memberikan batasan ke dalam beberapa pertanyaan mendasar yang memiliki keterkaitan langsung dengan pengetahuan, yaitu: Apa itu pengetahuan? Dimanakah pengetahuan itu diperoleh? Apa ukurannya agar pengetahuan itu dianggap benar-benar sebagai pengetahuan? Apakah inderawi menghasilkan pengetahuan? Dapatkah budi memberi pengetahuan? Apakah hubungan antara pengetahuan dengan keyakinan yang benar? Pertanyaan-pertanyaan inilah lebih lanjut dikembangkan oleh para pakar, sehingga epistemologi berfungsi sebagai pembangun kerangka 
sebuah disiplin ilmu yang pada perkembangan selanjutnya melahirkan dua pokok aliran, yaitu : Pertama, adalah aliran yang mengakui pentingnya peranan akal sebagai sumber ilmu pengetahuan. Aliran ini dikenal dengan aliran rasionalisme, karena cenderung mengabaikan peran empirisme. Sedangkan aliran yang kedua adalah aliran realisme atau emperisme yang lebih menekankan pada peran indera sebagai sumber sekaligus alat untuk memperoleh ilmu pengetahuan. Harus diakui bahwa wacana Komunikasi dan Penyiaran Islam memang masih agak sunyi kendati sebenarnya sudah bermunculan program studi atau konsentrasi keilmuan Komunikasi dan Penyiaran Islam, seperti halnya di Fakultas Dakwah dan Komunikasi UIN Sunan Kalijaga Yogyakarta. Pun diakui masih cukup muda dibandingkan dengan Komunikasi konvensional yang sudah mapan dan dikenal luas selama ini. Komunikasi dan Penyiaran Islam sendiri baru mendapat perhatian lebih serius dibanding sebelumnya terutama setelah diterbitkannya buku seperti Communication Theory: The Asian Perspective oleh The Asian Mass Communication Research and Information Centre, Singapura, tahun 1988. Di samping itu, Mohd. Yusof Hussain, menulis dalam Media Asia tahun 1986 dengan judul Islamization of Communication Theory, dan pada bulan Januari 1993, jurnal Media Culture and Society yang terbit di London juga memberi liputan kepada Komunikasi dan Penyiaran Islam. ${ }^{4}$ Perhatian terhadap Komunikasi dan Penyiaran Islam seperti di atas harus direspon secara positif dan hendaknya terus-menerus digalakkan pengkajian yang lebih serius, hingga pada akhirnya terbangun kerangka keilmuannya yang kokoh dan mapan.

\section{a. Epistemologi Keilmuan Komunikasi dan Penyiaran Islam}

Sebelum dikemukakan epistemologi Komunikasi dan Penyiaran Islam, terlebih dahulu dikemukakan beberapa gambaran konsep dasar tentang epistemologi secara umum dan dalam perspektif Islam. Pertamatama akan dikemukakan tentang cara-cara memperoleh ilmu pengetahuan. Di kalangan para pemikir, mulai dari masa Aristoteles hingga Freud atau dari zaman Yunani hingga zaman modern, telah terjadi perdebatan filosofis yang sengit di sekitar pengetahuan manusia. Salah satu perdebatan besar itu adalah diskusi yang mempersoalkan sumber-sumber dan asal-usul pengetahuan dengan meneliti, mempelajari dan mencoba mengungkapkan prinsip-prinsip primer kekuatan struktur pikiran yang dianugerahkan

${ }^{4}$ Syukur Kholil, Komunikasi dalam Perspektif Islam, dalam Hasan Asari \& Amroeni Drajat (ed.) Antologi Kajian Islam (Bandung: Cita Pustaka Media, 2004), hlm. 251. 
kepada manusia..$^{5}$ Mereka ingin menjawab pertanyaan-pertanyaan seputar: Bagaimana pengetahuan itu muncul dalam diri manusia? Bagaimana kehidupan intelektualnya tercipta, termasuk setiap pemikiran dan konsepkonsep (notions) yang muncul sejak dini? Dan apakah sumber yang memberikan kepada manusia arus pemikiran dan pengetahuan ini? Dengan mengkritisi pendapat-pendapat pemikir yang mendiskusikan tentang sumber-sumber dan asal-usul pengetahuan manusia itu, ${ }^{6}$ Muhammad Baqir Ash-Shadr mencari argumen sendiri untuk memberikan jawaban terhadap pertanyaan-pertanyaan sebagaimana di atas. Ia mengemukakan bahwa secara garis besar pengetahuan manusia itu di bagi menjadi dua, yaitu konsepsi (tashawwur) atau pengetahuan sederhana dan assent (tashdiq) atau pembenaran. ${ }^{7}$

Dalam banyak ayat Alquran dikemukakan tentang berbagai cara meperoleh ilmu pengetahuan, yaitu melalui persepsi inderawi, melalui kalbu atau akal, dan lewat wahyu atau ilham. 1) Pengetahuan indera. 2) Pengetahuan akal. 3) Pengetahuan wahyu atau ilham. ${ }^{8}$

Sebagaimana dikemukakan oleh Jalaluddin Rahmat, Alquran menunjukkan empat sumber untuk memperoleh pengetahuan: 1) Alquran dan Sunnah, 2) Alam Semesta, 3) Tarikh Umat Manusia ${ }^{9}$

Dengan demikian, paradigma Komunikasi dan Penyiaran Islam berdasarkan kepada Al Qur'an dan Sunnah sebagai sumber inspirasi epistemologi Komunikasi dan Penyiaran Islam dan penggabungannya terdapat pada studi tekstual dan studi kontekstual, yang meliputi alam semesta, diri manusia (anfus), dan tarikh umat manusia. Hal ini berarti bahwa kerangka keilmuan Komunikasi dan Penyiaran Islam dapat ditelusuri, meskipun sumber primer ilmu komunikasi Islam adalah Al Qur'an. ${ }^{10}$ Dengan demikian, rumusan, gagasan dan rancangan epistemologi ilmu Komunikasi Islam adalah kreasi manusia. Berdasarkan paradigma ini maka muncul kategorisasi bahwa Komunikasi dan Penyiaran Islam tergolong ke dalam komunikasi teokrasi atau pun juga komunikasi religius (keagamaan).

5 Sayyid al-Islam Ayatullah al-'Uzma as-Sayyid Muhammad Baqir Ash-Shadr, Falsafatuna (terj.) M. Nur Mufid bin Ali (Bandung: Mizan, 1995), hlm. 25.

${ }^{6}$ Kritik yang disampaikan oleh Muhammad Baqir Ash-Shadr dapat ditelusuri secara lebih mendalam di dalam bukunya Falsafatuna, hlm. 65-106.

7 Ibid. hlm.65.

8 Jalaluddin Rakhmat, Islam Alternatif: Ceramah-Ceramah di Kampus (Bandung: Mizan, 1999), hlm.206

${ }^{9}$ Ibid, hlm. 203-205.

${ }^{10}$ A. Muis. Komunikasi Islam (Bandung: Remaja Rosdakarya, 2001), hlm. 65. 
Epistemologi berbicara mengenai bagaimana cara ilmu pengetahuan ditemukan, dalam prosesnya scholar atau komunitas keilmuan akan berdiskusi mengenai penguatan terhadap objek atau hakekat realitas yang akan ditemukan (ontologi) dan sekaligus menempatkan diri dalam masalah keberpihakan nilai (aksiologi). 11

Menurut Hermin Indah Wahyuni ${ }^{12}$, jika ingin mempertajam keilmuan "komunikasi dan penyiaran Islam" maka perlu kita kupas satu persatu mengenai tiga domain kajian, pertama konteks keilmuan " komunikasi" kedua, sub domain komunikasi yakni "penyiaran," serta ketiga Islam sebagai warna nilai yang menjiwai dan memandunya. Terkait dengan obyek kajian, dunia ilmu komunikasi memiliki realitas objek yang sangat luas sehingga tidak cukup mudah ditentukan batasannya. Walaupun demikian hingga saat ini jika berbicara mengenai komunikasi setidaknya terdapat lima elemen yang akan dikaji, pertama adalah mengenai proses komunikasi dengan lima elemen yang menjadi struktur dasarnya (komunikator, pesan, media, komunikan, dan efek). ${ }^{13}$ Untuk membahasnya setidaknya terdapat tujuh tradisi dalam mendefinisikan komunikasi. Mulai dari tradisi retorika, socio-cultural, socio-psikologis, phenomenologis, semiotika, kritis dan sibernetika. ${ }^{14}$

Penyiaran sendiri merupakan bentuk sub-bidang dalam proses komunikasi massa yang menggunakan media audio dan visual dengan implikasi yang spesifik dalam kaitan dengan efek pada audiencenya. Jika keduanya digabungkan, beberapa pertanyaan sentralnya adalah apakah memang kajian KPI dimaksudkan mengkaji domain komunikasi dengan tekanan spesifik lebih menyoroti kajian penyiaran? Ataukah dua-duanya menjadi fokus kajian dengan interest yang sama? Bagaimana nilai keislaman diinternalisasikan sebagai nilai inti dalam proses tersebut?.

Sebagai upaya mempertegas batas keilmuan antara kajian komunikasi dan penyiaran islam dengan kajian komunikasi dan penyiaran di luar dirinya, tiga bangunan filosofi keilmuan di atas (isu ontologi,

11 Benton, Ted dan Craib, Ian. 2001. Philosophy of Social Science, the philosopohical foundations of social thought. New York: Palgrave. hlm. 1-11

12 Hermin Indah Wahyuni, Epistemologi Komunikasi dan Penyiaran Islam, disampaikan dalam Seminar Nasional dan Forkopis se-Indonesia, Yogyakarta: University Hotel UIN, 8-10 Oktober 2013, hlm. 1.

13 West, Richard \& Lynn H. Turner. Introducing Communication Theory: Analysis and Application. (Boston: McGraw-Hill. 2010), hlm. Bab 1.

14 Craig, Robert T, Muller, Heidi L., Theorizing Communication. Reading Across Traditions (USA: Sage Publications, 2007). 
epistemologi dan aksiologi) tentunya harus dideskripsikan dengan tepat. Sehingga karakter dan kekhasan KPI akan muncul. ${ }^{15}$

Persoalan pertama dari isu ontologi, bagaimana realitas akan dihadirkan. Bangunan regional ontologi perlu untuk dipertegas batasbatasnya. Apa saja fenomena komunikasi dan penyiaran islam yang menjadi "concern" untuk diselesaikan? Untuk menangkap problem maka bangunan teori yang digunakan untuk menangkap fenomena pun harus diperkuat. Misalnya saat membicarakan mengenai teori-teori komunikasi, jika bidang komunikasi umum berbicara mengenai komunikasi di berbagai levelnya, maka di KPI perlu ada tambahan kontemplasi nilai keislaman pada teori-teori tersebut. Sehingga pada akhirnya mahasiswa akan melihat perbedaan signifikan jika dibandingkan dengan teori komunikasi yang tidak dikaitkan dengan nilai tertentu. Dosen tampaknya perlu menjadi pelopor dalam mentransformasikan aspek-aspek kajian yang menjadi objeknya sehingga akan menginspirasi mahasiswa dalam menangkap fenomena-fenomena di sekitar dirinya dengan perspektif keislaman yang kuat

Problem epistemologi terkait dengan bagaimana proses pengetahuan ditemukan. Karakter obyek yang jelas akan melahirkan pencarian data dengan penggunaan metode penelitian yang spesifik baik dari tradisi teori yang digunakan hingga metode yang digunakan (kuantitatif ataupun kualitatif). Dalam konteks kajian KPI, pertanyaan pentingnya adalah bagaimana argumentasi disusun untuk menguatkan logika pencarian keilmuan dalam warna perspektif keislaman dapat dispesifikasikan.

Problem aksiologi terkait dengan relasi nilai antara peneliti dan yang diteliti. Pilihan apakah sebuah penelitian bebas nilai, ataupun dibebani oleh nilai tertentu merupakan hal yang menjadi fokus dari kajian aksiologi. Pada titik inilah jika memang dalam kajian KPI nilai-nilai keislaman yang menjadi acuan maka penilaian terhadap berbagai fenomena hendaknya dimunculkan dalam warna analisis yang sudah sewajarnya kental dengan pemihakan pada nilai keislaman. Posisinya dapat dikatakan sangat kental diwarnai oleh paradigma normatif yang berangkat dari sebuah idealisme keislaman, ataupun pada posisi kritis dimana penulis beremansipasi secara ideologis dengan karyanya. Dengan mewarnai seluruh tahapan pencarian keilmuan dengan warna keislaman, maka pada akhirnya akan terwujud sebuah eksistensi keilmuan yang kuat dengan batasan problem yang jelas dan dapat dibedakan dari konteks kelimuan komunikasi yang lainnya.

${ }^{15}$ Lihat, Hermin Indah Wahyuni....hlm.3. 
Jika demikian halnya, maka dapatkah Komunikasi dan Penyiaran Islam dijadikan sebagai suatu ilmu? Pertanyaan ini layak diajukan, ketika Komunikasi Islam dimasukkan ke dalam komunikasi teokrasi atau komunikasi religius, sebab pastilah ia akan bersumber dari yang tidak bisa dijangkau secara utuh oleh rasionalitas manusia, melainkan melalui satu jalan yang harus diyakini yaitu adanya wahyu atau ilham. Ada beberapa syarat, agar suatu disiplin ilmu dipandang mampu berdiri sendiri, yaitu: Memiliki objek tersendiri (yang dikaji oleh satu aspek dalam filsafat ilmu, yaitu ontologi), bersifat empiris, sistematis, universal, dapat diverifikasi dan mempuyai nilai guna bagi kehidupan manusia. Tanpa harus didahului oleh kecurigaan ataupun juga simpati yang berlebihan, Komunikasi Islam sebagai hasil pemikiran ilmiah manusia tentu bersifat dinamis dan tidak bisa terlepas dari pengujian terhadap tingkat kebenaran ilmu. Pemakaian kata Islam adalah merupakan ciri khas dari bentuk teori dan prinsip yang dibangun sesuai dengan tata nilai dan aturan, agar manusia menjalani hidupnya sesuai dengan aturan-aturan-Nya.

Di sisi lain, memang harus diakui adanya pendekatan-pendekatan yang harus ditempuh untuk melihat bahwa Komunikasi Islam benar sebagai suatu disiplin ilmu. Oleh karena itulah, keabsahan keilmuan komunikasi Islam dapat juga disejajarkan dengan bentuk analisis disiplin ilmu lainnya, seperti filsafat, psikologi, antropologi, sosiologi dan sejarah, karena ilmuan komunikasi Islam mempunyai kedekatan relasi kuasa antara teks dengan konteks yang berdasarkan data dan fakta. Namun harus disadari bahwa doktrin normatif al-Qur'an tidak bisa digangu gugat dengan mereduksi ayat dalam rangka meyesuaikan dengan realitas yang ada, meskipun keilmuannya tetap pada wilayah dinamika ilmu. ${ }^{16}$

Dengan demikian, jelaslah bahwa ilmu komunikasi Islam sesungguhnya mempunyai struktur keilmuan yang jelas dan konkrit sebagaimana halnya ilmu-ilmu lain. Jika ini bisa diterima, maka sebenarnya posisi ilmu komunikasi Islam berada pada wilayah tingkat kebenaran ilmu, bukan tingkat kebenaran agama. Oleh karena itu, Komunikasi dan Penyiaran Islam dapat dikatakan sebagai suatu disiplin ilmu.

\section{b. Rumpun Keilmuan Komunikasi dan Penyiaran Islam}

Dengan pengembangan daya pikir dan cara berpikir manusia, dewasa ini asas pengaturan pengetahuan (kennis, knowledge) yang dilakukan hlm. 67 .

16 Andy Dermawan, dkk (ed). Metodologi Ilmu Dakwah (Yogyakarta: LESFI, 2002), 
secara taat asas dan konsisten, ${ }^{17}$ maka berkembang pengetahuan ilmiah atau ilmu, yakni pengetahuan yang tersusun secara sistematis dan sistemis tentang sesuatu18. Dalam khazanah pengetahuan ilmiah itu, gejala kehidupan atau sesuatu itu dik;enal sebagai obyek (material). Ia dapat dilihat dari berbagai sudut pandang, yang kemudian dikenal sebagai obyek formal. Dengan pemilahan obyek tersebut, maka dikenal beberapa disiplin ilmu, kemudian subdisiplin ilmu. Dewasa ini dikenal beberapa disiplin ilmu dalam rumpun ilmu-ilmu alamiah, dalam rumpun ilmu-ilmu sosial atau ilmu-ilmu perilaku manusia, dan dalam rumpun ilmu-ilmu budaya (humaniora).

Pertumbuhan dan perkembangan berbagai disiplin ilmu itu berbarengan dengan pengembangan unsur-unsur pengetahuan ilmiah, yaitu unsur substansi (pemilahan obyek dari sesuatu atau kehidupan), unsur informasi, dan unsur cara memperoleh, menyusun dan merumuskan informasi tentang substansi, yang kemudian dapat disebut sebagai unsur metodologi masing-masing disiplin ilmu itu. Dengan perkataan lain, masing-masing ilmu itu hanya dapat berkembang manakala paralel dengan pengembangan ketiga unsur itu. Sebaliknya, apabila pengembangannya hanya dicurahkan pada salah unsur, maka akan mengalami kemacetan dan kemandegan. Ilmu hanya akan menjadi benda pusaka yang pantas dilestarikan, tetapi tidak memiliki dayaguna untuk memahami dan menjelaskan kehidupan yang semakin rumit. Demikian pula, tak berdaya untuk menunjang kehidupan makhluk Allah.

Klasifikasi berbagai disiplin dan subdisiplin ilmu itu ke dalam tiga rumpun ilmu didasarkan pada pemilahan sasaran pengkajian masingmasing, yakni subject matter (obyek material dan formal). Sasaran pengkajian ilmu-ilmu alamiah ialah gejala-gejala alamiah. Sasaran pengkajian ilmu-ilmu sosial ialah gejala-gejala perilaku manusia. Dan sasaran pengkajian ilmu-ilmu budaya ialah gejala-gejala budaya, yakni aspek ruhaniah dan aspek normatif dalam kehidupan manusia, yang mencakup keyakinan, nilai, dan kaidah yang dijadikan patokan dan ekspresi dalam kehidupan manusia. Seluruh gejala yang dijadikan sasaran pengkajian dari berbagai disiplin ilmu itu adalah gejala kehidupan, di

17 Fuad Hassan dan Koentjaraningrat. "Beberapa Azas Metodologi Ilmiah", dalam Koentjaraningrat (Redaksi), Metode-metode Penelitian Masyarakat, Cetakan Kedua, (Jakarta: Gramedia, 1977) . hlm. 8-23.

18 Menurut ketentuan Pasal 1 butir (1) UU Nomor 18 Tahun 2002 yang dimaksud dengan ilmu pengetahuan adalah rangkaian pengetahuan yang digali, disusun, dan dikembangkan secara sistematis dengan menggunakan pendekatan tertentu yang dilandasi oleh metodologi ilmiah, baik yang bersifat kuantitatif, kualitatif, maupun eksploratif untuk menerangkan pembuktian gejala alam dan/atau gejala kemasyarakatan tertentu. 
antaranya gejala kehidupan manusia. Atau dengan perkataan lain, sasaran pengkajian tersebut ialah keseluruhan ciptaan Allah Swt., antara lain, dapat dipahami dari ayat-ayat Qur'an (ayat qauliyah). Secara umum, seluruh gejala tersebut dapat dipandang sebagai wujud aktual dari berbagai hukum (keteraturan) ${ }^{19}$ dalam suatu kesatuan hukum Allah (Tawhìd 'l-Lāh) yakni hukum Tuhan Yang Maha Pencipta dan Yang Maha Pengatur.

Demikian pula, dalam ilmu-ilmu sosial mencakup berbagai ilmu dasar dan ilmu terapan, termasuk ilmu hukum, yang dewasa ini, berada di antara ilmu-ilmu sosial dan ilmu-ilmu budaya. Koentjaraningrat, ${ }^{20}$ misalnya, memilah ilmu-ilmu sosial menjadi dua pilahan, yakni ilmu dasar dan ilmu terapan. Ilmu dasar terdiri atas ilmu sejarah, geografi, linguistik, antropologi, sosiologi, dan psikologi. Sedangkan ilmu terapan terdiri atas ilmu ekonomi, ilmu politik, ilmu administrasi, ilmu komunikasi, ilmu hubungan internasional, ilmu hukum (untuk profesi hukum), dan demografi.

Sementara itu, ilmu dakwah dikelompokkan ke dalam rumpun ilmuilmu sosial didasarkan kepada pandangan bahwa yang menjadi obyek ilmu itu adalah kegiatan penyebarluasan agama Islam dalam kehidupan masyarakat, individual dan kolektif. Ia dapat dirumuskan sebagai: apa diserukan atau disebarkan oleh siapa, kepada siapa, dengan cara bagaimana, melalui media apa, dan untuk apa. Selaras dengan hal itu, Amrullah Ahmad ${ }^{21}$ menyatakan bahwa ilmu dakwah merupakan ilmu sosial (ilmu kemasyarakatan Islam), dengan obyek formal gejala dan kegiatan dakwah Islam. Selanjutnya, ia membagi tiga disiplin utama, yakni disiplin ilmu tabligh (komunikasi dan penyiaran Islam; serta bimbingan dan penyuluhan Islam); disiplin ilmu pengembangan masyarakat Islam; dan disiplin ilmu manajemen dakwah.

Berdasarkan analisa yang ada dapatlah ditarik kesimpulan bahwa rumpun keilmuan jurusan Komunikasi dan Penyiaran Islam adalah pengkajian disiplin Ilmu Komunikasi dengan bidang kajiannya broadcasting dan jurnalistik serta lainnya. Sedangkan Penyiaran Islam

19 Yang dimaksud dengan hukum dalam tulisan ini adalah pernyataan umum tentang keteraturan-keteraturan yang selalu terjadi dalam bentuk yang sama, yang berlaku tanpa batas waktu dan tempat tertentu (Lihat: Wuisman, 1996: 186).

${ }^{20}$ Koentjaraningrat. "Kemurnian Ilmu Pengetahuan dan Tanggung Jawab terhadap Masyarakat", dalam Ismid Hadad dan Rusdi Mochtar (Redaksi), Etika Ilmu Pengetahuan dan Peningkatan Mutu Kesarjanaan, (Jakarta: Himpunan Indonesia untuk Pengembangan Ilmuilmu Sosial. 1977), hlm. 66-76.

21 Amrullah Ahmad. Materi dan Metode Penyajian Disiplin Dakwah Islam dalam Kurikulum IAIN 1995. Makalah disampaikan dalam Orientasi Kurikulum Nasional IAIN dan Topik Intinya, pada tanggal 18 Mei 1995, di Jakarta. hlm. 4. 
sebagai bidang kajian Ilmu Dakwah yang menjadi core values dengan perspektif Islamnya. Hal ini menjadi selaras dengan visi jurusan Komunikasi dan Penyiaran Islam yaitu terdepan dalam pengkajian dan pengembangan ilmu-ilmu komunikasi dan penyiaran Islam yang berparadigma Islam.

Untuk mencapai visi yang dideklarasikan, selanjutnya bisa dipetakan dua dorongan, baik yang bersifat keilmuan, maupun yang bersifat keahlian (tuntutan pasar). Kompetensi keilmuan dikembangkan oleh jurusan dengan mempertimbangkan seluruh perkembangan mutakhir dalam bidang keilmuan. Melalui kompetensi keilmuan inilah tanggungjawab pengembangan teori dan metodologi dalam mendorong pengembangan keilmuan dirumuskan. Jurusan dapat mendesain kurikulumnya sedemikian rupa sehingga penguasaan mahasiswa pada ranah keilmuan dapat diwujudkan. Dalam kaitan ini, prodi meletakkan dasar-dasar kompetensi keilmuannya sesuai dengan nilai perjuangan yang telah ditegaskan.

Sedangkan kompetensi keahlian adalah kompetensi untuk trampil dalam praktek di dunia kerja di pemerintah, masyarakat sipil, dan bisnis yang dirumuskan berdasarkan kebutuhan pasar kerja (market demands) dengan memodali lulusan dalam penguasaan skill (ketrampilan) termutakhir yang ada di lapangan kerja. Kompetensi keahlian dikembangkan oleh prodi dengan mempertimbangkan seluruh perkembangan mutakhir sesuai dengan perkembangan profesi dan keahlian. Dalam penyusunannya prodi berkomunikasi secara aktif dengan board of professionals yang dapat memberikan masukan-masukan terkait perkembangan di ranah praktis. ${ }^{22}$

Selanjutnya kurikulum dapat dikategorikan dalam tiga bentuknya dimana bisa bersifat intra kurrikuler, ko-kurikuler, dan ekstra-kurikuler. Proses pembelajaran intra kurikuler merupakan pembelajaran normal yang biasa dilakukan. Ko-kurikuler merupakan bentuk pembelajaran yang tidak harus di kelas namun disinergikan dalam muatan inti kurikulum. Misalnya mahasiswa jurusan KPI yang dapat menunjukkan kemampuan berbahasa asing dengan standar yang baik dapat diapresiasi. Demikian pula mereka yang mampu menunjukkan capaian prestasi yang relevan bisa dihargai. Mahasiswa saat ini memiliki banyak kesempatan untuk berkiprah di luar kampus, bagi mereka yang bisa memanfaatkannya dapat diapresiasi jika memenuhi syarat-syarat yang telah ditentukan. Selanjutnya ekstrakurikuler bagi mahasiswa jurusan KPI dapat dibuatkan unit-unit kegiatan yang memiliki relevansi dengan domain kajian dalam perkuliahan.

${ }^{22}$ Lihat, Hermin Indah Wahyuni,... hlm. 5. 
Rangkaian logika kurikulum dapat digambarkan dalam segitiga di bawah ini:

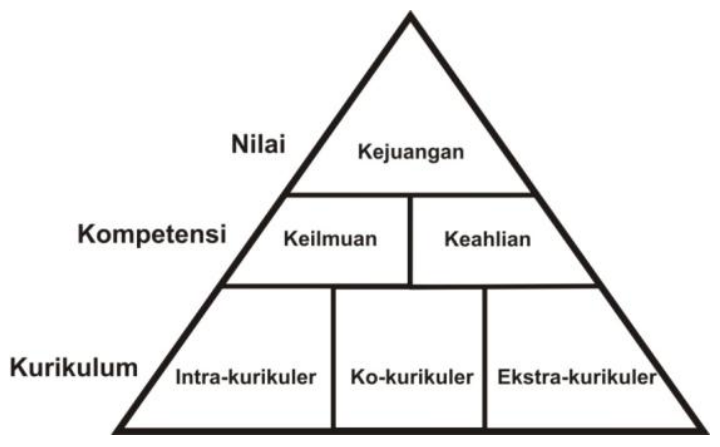

Gambar 1. Argumen Kurikulum²3

Demikianlah karena ilmu komunikasi merupakan ilmu yang sangat khas, dengan dua karakter dimensi antara seni dan ilmu, maka sangat dituntut kekreatifitasan para pengelola untuk dapat memadukan komposisi yang tepat dalam pengajarannya. Ilmu ini membutuhkan pengayaan secara teori tetapi sekaligus memiliki aspek praktis dan ketrampilan yang kental.

Dari pengalaman yang ada, pertanyaan penting yang muncul adalah jumlah satuan kredit semester dalam pengajaran. Di beberapa Perguruan Tinggi masih menyelenggarakan pendidikan ilmu komunikasi dengan beban total 144 sks. Saat itulah para assessor mempertanyakan jumlah SKS ini yang menurut mereka sangat ambisius dan cenderung generalis sehingga menjadikan kajian kurang tajam. Hingga saat ini sedang dipikirkan bagaimana meresponnya. Terlihat ilmu komunikasi di Indonesia memiliki rata-rata jumlah sks sebanyak 144 sks atau bahkan lebih. Isu ini mungkin juga perlu untuk mendapat sentuhan penajaman sehingga dengan perombakan kurikulum akan dapat menghasilkan Expected Learning Outcomes (ELO) yang semakin baik.

Pada akhirnya dengan upaya untuk terus mempertajam fokus kajian, maka Jurusan Komunikasi dan Penyiaran Islam (KPI) Fakultas Dakwah dan Komunikasi UIN Sunan Kalijaga Yogyakarta akan mampu melahirkan lulusan yang memiliki keilmuan dan ketrampilan yang relevan sebagai ahliahli di bidang komunikasi dan penyiaran dengan basis perspektif keislaman. Perlu keberanian untuk menentukan karakter diri dengan mengambil informasi yang spesifik dari lingkungan, tidak ada supertheory

23 Buku Kurikulum Fisipol UGM 2011-2016 
yang dapat menawarkan solusi tunggal. Pada tahap ini evolusi sistem internal dengan melihat tuntutan lingkungan yang berubah akan melahirkan serangkaian perubahan baik dari penguatan substansi ataupun desain institusional penyelenggaraan jurusan KPI. Diharapkan struktur yang lahir sebagai adaptasi terhadap problem spesifik lingkungan di Indonesia akan mampu menyelesaikan problem-problem yang juga bersifat spesifik di Indonesia.

\section{Penutup}

Berdasarkan pemaparan di atas, terkait dengan Epistemologi dan Rumpun keilmuan Komunikasi Penyiaran Islam, maka kiranya dapat disimpulkan secara sederhana sebagai berikut. Secara jelas dapat disimpulkan bahwa epistemologi keilmuan jurusan Komunikasi dan Penyiaran Islam adalah pengkajian disiplin Ilmu Komunikasi dengan bidang kajiannya broadcasting dan jurnalistik serta lainnya. Sedangkan Penyiaran Islam sebagai bidang kajian Ilmu Dakwah yang menjadi core values dengan perspektif Islamnya. Hal ini menjadi selaras dengan visi jurusan Komunikasi dan Penyiaran Islam yaitu terdepan dalam pengkajian dan pengembangan ilmu-ilmu komunikasi dan penyiaran Islam yang berparadigma Islam. 


\section{DAFTAR PUSTAKA}

Abdullah, M. Amin, Islamic Studies di Perguruan Tinggi: Paradigma Integratif-Interkonektif, Cet II. (Yogyakarta: Pustaka Pelajar, 2010).

Amrullah Ahmad. 1995. "Materi dan Metode Penyajian Disiplin Dakwah Islam dalam Kurikulum IAIN 1995". Makalah disampaikan dalam Orientasi Kurikulum Nasional IAIN dan Topik Intinya, pada tanggal 18 Mei 1995, di Jakarta.

A. Muis. Komunikasi Islam, (Bandung: Remaja Rosdakarya, 2001).

Andy Dermawan, dkk (ed). Metodologi Ilmu Dakwah, (Yogyakarta: LESFI, 2002).

Badan Standar Nasional Pendidikan, Panduan Penyusunan Kurikulum Tingkat Satuan Pendidikan Jenjang Pendidikan Dasar dan Menengah, (Jakarta : BSNP, 2006).

Blazely, Lloyd D. et.all, Science Study, (Jakarta: The Japan Grant Foundation, 1997).

BPMPT (Badan Penjaminan Mutu Pendidikan Tinggi. SOP Laboratorium, (Dokumen Level Prosedur Operasional Baku). Universitas Negeri Gorontalo. (Makasar. 2006).

Benton, Ted dan Craib, Ian. Philosophy of Social Science, the philosopohical foundations of social thought. (New York: Palgrave. 2001).

Craig, Robert T, Muller, Heidi L., Theorizing Communication. Reading Across Traditions.(USA: Sage Publications, 2007).

Effendy, Onong U. Ilmu, Teori dan Filsafat Komunikasi. (Bandung: Citra Aditya Bakti. 2007).

Fuad Hassan dan Koentjaraningrat. 1977. "Beberapa Azas Metodologi Ilmiah", dalam Koentjaraningrat (Redaksi), Metode-metode Penelitian Masyarakat, Cetakan Kedua, hlm. 8-23. Jakarta: Gramedia.

Gerad Radnitzky, Contemporar School of Metascience. (Swedia: Berlingska Broktryckercit. 1970).

Gregory, Anne. Planning \& Managing A Public relations Campaign. (New Delhi: Crest, 2000).

Hermin Indah Wahyuni, Epistemologi Komunikasi dan Penyiaran Islam, disampaikan dalam Seminar Nasional dan Forkopis se-Indonesia, Yogyakarta: University Hotel UIN, 8-10 Oktober 2013. 
Iriantara, Yosal. Manajemen Strategis Public Relations. (Jakarta: Ghalia Indonesia, 2004).

Jalaluddin Rakhmat, Islam Alternatif: Ceramah-Ceramah di Kampus, (Bandung: Mizan, 1999).

Koentjaraningrat. "Kemurnian Ilmu Pengetahuan dan Tanggung Jawab terhadap Masyarakat", dalam Ismid Hadad dan Rusdi Mochtar (Redaksi), Etika Ilmu Pengetahuan \& Peningkatan Mutu Kesarjanaan, hlm. 66-76. (Jakarta: Himpunan Indonesia untuk Pengembangan Ilmu-ilmu Sosial. 1977).

Sayyid al-Islam Ayatullah al-'Uzma as-Sayyid Muhammad Baqir Ash-Shadr, Falsafatuna (terj.) M. Nur Mufid bin Ali, (Bandung: Mizan, 1995).

Soemirat, Soleh. Dasar-Dasar Public Relations. (Bandung: PT. Remaja Rosdakarya 2008).

Syukur Kholil, "Komunikasi dalam Perspektif Islam", dalam Hasan Asari \& Amroeni Drajat (ed.) Antologi Kajian Islam, (Bandung: Cita Pustaka Media, 2004).

Sudarsono, Ilmu Filsafat: Suatu Pengantar, (Jakarta: Rineka Cipta, 2001).

Salmadanis. Menggagas Kembali Eksistensi Ilmu Dakwah. Dalam Jurnal Komunikasi dan Pemikiran Islam. Vol. 4 No. 1 April 2006.

West, Richard \& Lynn H. Turner. Introducing Communication Theory: Analysis and Application. (Boston: McGraw-Hill. 2010).

\section{Sumber Lain:}

Buku Kurikulum Fisipol UGM 2011-2016

Buku Pedoman Akademik dan Kode Etik Mahasiswa UIN Sunan Kalijaga Yogyakarta, edisi revisi 2012.

Dokumen Rencana Mutu, RM-UINSK-FDy/R2, revisi tanggal 5 Januari 2012

Profil Jurusan Komunikasi dan Penyiaran Islam (KPI) 2011

UINSUKA, Profil Universitas Islam Negeri Sunan Kalijaga Yogyakarta., Yogyakarta: 2006

Undang-Undang RI. Nomor 20 Tahun 2003, Tentang Sistem Pendidikan Nasional 